\title{
Status of testing field for ocean energy generation
}

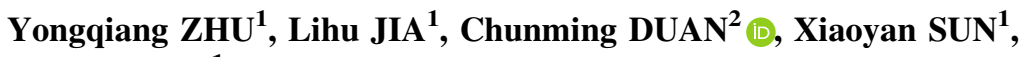 \\ Wenrui GUO ${ }^{1}$
}

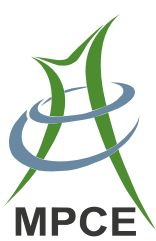

\begin{abstract}
Ocean energy, considered as clean energy, is one kind of marine resources of great importance. Its development and utilization have become an indispensable part of national development strategy in China. Testing fields are required when conducting tests of ocean energy generation devices in real sea, which is the key step conducted before engineering prototypes transformed into scale industrialization applications. This paper introduces the construction and operation conditions of large-scale testing fields for wave energy and tidal current energy generation devices and presents a brief comparative analysis. Developing status and related technologies on testing fields for ocean energy power generation in China are also discussed. Furthermore, this paper investigates the necessity of grid-connected test for ocean energy generation and points out that the construction of ocean energy testing fields is helpful to ensure the efficient utilization of ocean energy resources.
\end{abstract}

CrossCheck date: 30 March 2015

Received: 18 December 2013/Accepted: 1 March 2015/Published online: 26 September 2015

(C) The Author(s) 2015. This article is published with open access at Springerlink.com

$\triangle$ Chunming DUAN

809296632@qq.com; zyq@ncepu.edu.cn

1 North China Electric Power University, Beijing 102206, China

2 State Grid Jibei Electric Economic Research Institute, Beijing 100045, China
Keywords Wave energy, Tidal current energy, Testing field, Ocean energy generation

\section{Introduction}

Ocean energy consists of wave energy, tidal energy, ocean current energy, temperature difference energy, salinity gradient energy, island wind energy, solar energy, etc. Utilizing renewable ocean energy is one of the strategies to realize economic and social sustainable development in coastal states [1].

At present, the technology to utilize wave energy and tidal current energy in China is still in its infancy stage. In southeast coastal areas, such as Fujian Province and Guangdong Province, wave energy generation devices are being experimented [2]. However, no public testing fields have been built for these devices in China. To reduce the risk of investment, it is necessary to conduct detailed experiments in real sea for a long period of time to evaluate the performances of ocean energy generation technologies before commercial applications. For preparation of tests in real sea, long-term investigations into status of ocean energy resources, hydrologic meteorological environment and seafloor sediments in test waters are needed. Afterwards, engineering projects such as submarine infrastructure construction, submarine cable casting and grid connection should also be carried out. The preparation stated above consumes a large amount of manpower and resources, which will greatly enlarge experiment cost and test duration [3]. Furthermore, these devices can only be promoted into large-scale business application after verified by economic evaluation index (cost, efficiency and reliability, etc.) [4]. Therefore, the construction of public testing fields becomes the most efficient way to solve the aforementioned problems. 


\section{Overview of existing ocean energy testing fields abroad}

Testing fields for ocean energy generation devices, referred to ocean energy testing fields later, are constructed to examine the performance of power conversion devices and related technologies of wave energy, tidal current energy and other types of ocean energy before their commercial application. Many leading countries in ocean energy exploitation have put tremendous resources into the construction of testing fields. To date, more than ten ocean energy testing fields have been built worldwide $[5,6]$.

Ocean energy testing fields have been put into operation or about to be put into operation mainly include: Nissum Bredning Test Station, located in the west coast of Denmark, was put into operation in 2003 [7]. Hanstholm Test Station, with desirable waves and water depth condition [8], was put into operation in 2009. Galway Bay in Reland was brought into use in 2003 [9]. The construction of Belmullet wave energy devices testing field was completed in 2012 [10]. The ocean energy testing field built by Europe Marine Energy Center (EMEC) in Orkney Scotland completed construction in 2004 [11]. Pilot Zone in northern Portugal, adjacent to Nazare, started operation in 2008 [12]. Wave Hub project in UK can be applied to perform gird-connected tests for various types of wave energy conversion devices [13]. SEM-REV in Loire, adjacent to City Nantes of France, completed construction in 2013 [14]. Biscay Marine Energy Platform (BIMEP) in north coast of Spain was built in 2011 [15, 16].

The major technical parameters of the main testing fields for wave energy and tide current energy are shown in Table 1 and Table 2.

\section{Abroad typical marine energy testing fields}

\subsection{EMEC}

EMEC offers services of maritime trials and testing for wave energy and tidal current energy conversion devices and related technologies. Under the guidance of European Commission (EC), UK and Scotland, advocating vigorously developing renewable energy, EMEC has become an internationally famous authoritative testing and certification center for marine energy conversion devices.

By now, EMEC possesses a wave energy on-site test station in Billia Croo, southwest of Orkney mainland, and a tidal current energy test site in the channel of Fall of Warness in north of the Eday Island. Orkney possesses considerable natural wave energy resources. The testing field there uninterruptedly receives waves up to $15 \mathrm{~m}$ high from the Atlantic. Furthermore, connecting to the northern boundary of state grid of UK, Orkney owns excellent port facilities. The tidal current test site in Eday Island has the fastest tidal current velocity in Europe which is up to $4 \mathrm{~m} / \mathrm{s}$. Besides, EMEC owns many certification qualifications such as power procurement, access to grid and devices testing, etc.

\subsubsection{Wave energy testing field owned by EMEC}

The location of wave energy testing field in Billia Croo, which is situated in the southwest of Orkney, is shown in Fig. 1. There are totally 5 test berths in the wave energy testing field in Billia Croo.

Wave energy testing field owned by EMEC is shown in Fig. 2. Position 1 in Fig. 2 is a test berth with five $11 \mathrm{kV}$ submarine cables lain in depth of $50 \mathrm{~m}$. These test points are $0.5 \mathrm{~km}$ apart from each other, where developers of

Table 1 Major testing fields for wave energy abroad

\begin{tabular}{lllll}
\hline Testing field (date of construction/operation) & Country & Wave energy density $(\mathrm{kW} / \mathrm{m})$ & Offshore distance $(\mathrm{km})$ & Depth of water $(\mathrm{m})$ \\
\hline Nissum bredning (2003) & Denmark & & 0.20 & 3.5 \\
Hanstholm (2009) & Denmark & & 0.50 & $30.0-50.0$ \\
Galway bay (2006) & Reland & 2.44 & 1.00 & 22.0 \\
Belmullet (2012) & Reland & $55.00-60.00(50.00 \mathrm{~m})$ & 7.00 & $20.0-100.0$ \\
& & $70.00-75.00(100.00 \mathrm{~m})$ & & $3.0-7.50$ \\
Pilot zone (2008) & Portugal & $21.00-25.00$ & $1.00-2.00$ & $30.0-90.0$ \\
EMEC (2004) & UK & 21.00 & 16.00 & $35.0-75.0$ \\
Wave hub (2011) & UK & 17.00 & 15.00 & 50.0 \\
SEM-REV (2013) & France & 14.40 & 0.75 & 35.0 \\
BIMEP (2011) & Spain & 21.00 & 3.20 & $50.0-90.0$ \\
Oregon (2008) [17] & U.S. & & 0.50 & $45.0-55.0$ \\
Runde (2009) [18] & Norway & & $30.0-50.0$
\end{tabular}


Table 2 Major testing fields for tide current energy abroad

\begin{tabular}{lllll}
\hline Test site (date of construction/operation) & Country & Flow velocity $(\mathrm{m} / \mathrm{s})$ & Offshore distance $(\mathrm{km})$ & Depth of water $(\mathrm{m})$ \\
\hline Force bay of fundy (2009) & Canada & 5.0 & & 45 \\
SOEC (2014) [19] & UK & $2.0-4.5$ & $<8$ & $18-42$ \\
ECMC (2007) & UK & $1.5-4.0$ & $1-4$ & $25-50$ \\
\hline
\end{tabular}

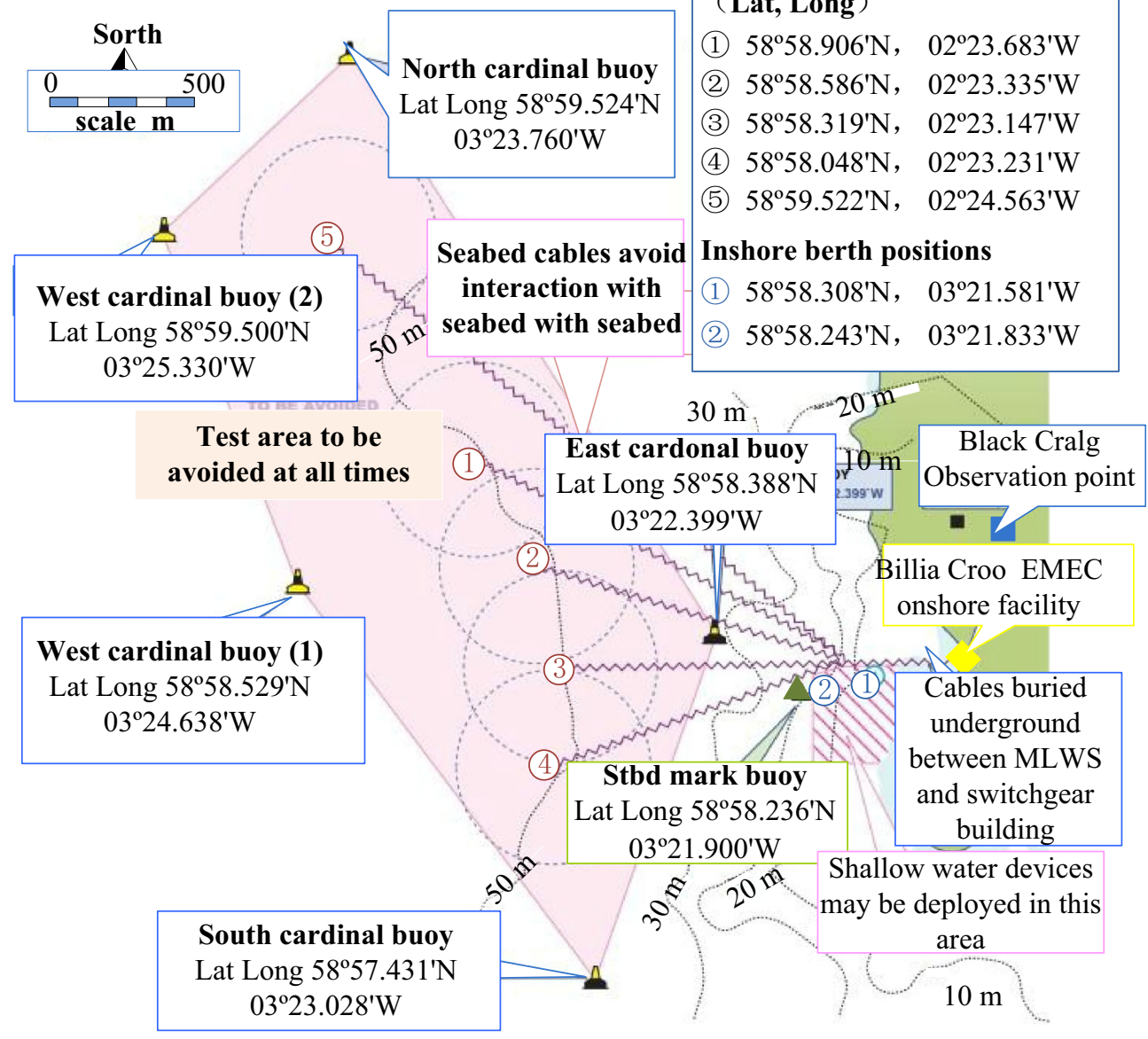

Fig. 1 Location of wave testing field owned by EMEC

wave energy converters can install mooring equipment, cable interface and power generation equipment. Position 2 is an onshore substation, including switch cubicles, standby units and communication lab. Monitoring equipment in the substation measures the power output characteristics of the devices in the testing field and sends the result to the data center. Position 5 is the Black Craig monitoring station, equipped with advanced camera. Position 7 represents the offices and data centers of EMEC. Position is the gridconnection area of the wave energy testing field, where the power generated by the wave energy converters is sent to the transformer through cables and then feed to the state grid directly.

\subsubsection{Tidal current energy testing field owned by EMEC}

The tidal current testing field in the channel of Fall of Wariness, located in west coast of the Eday Island, is labelled in Fig. 3. There are seven test berths within an area of $2 \mathrm{~km}$ width in the testing field. Seven $11 \mathrm{kV}$ submarine cables connect the test devices to the bank. 


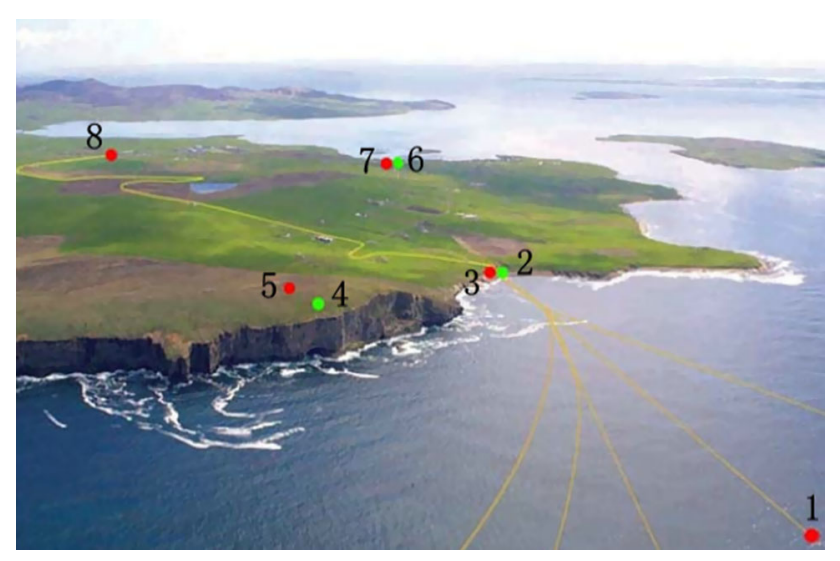

Fig. 2 Wave energy testing field owned by EMEC

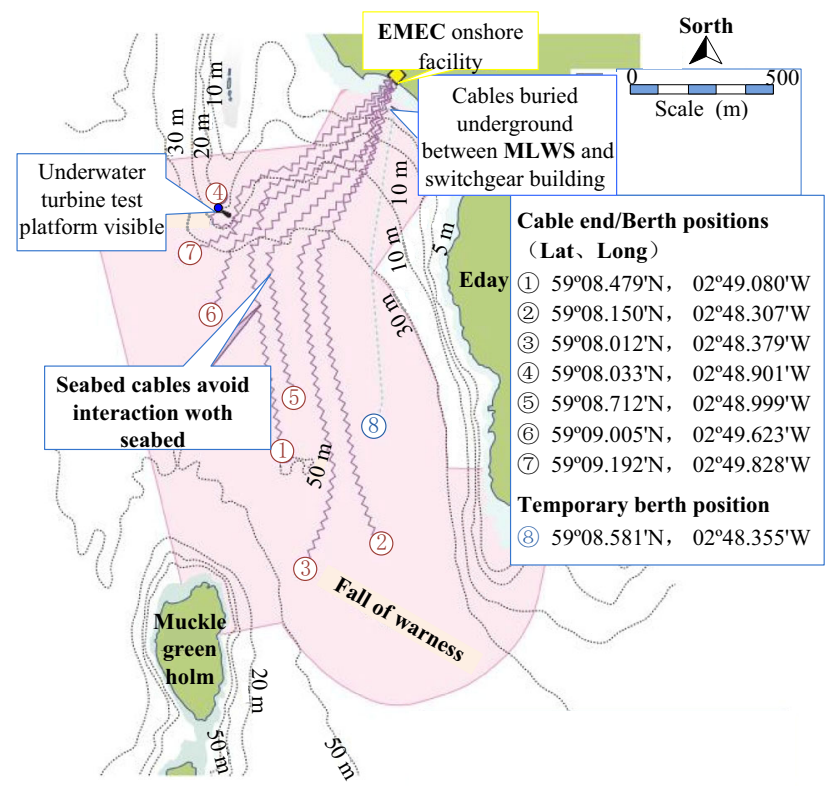

Fig. 3 Location of EMEC tidal testing field

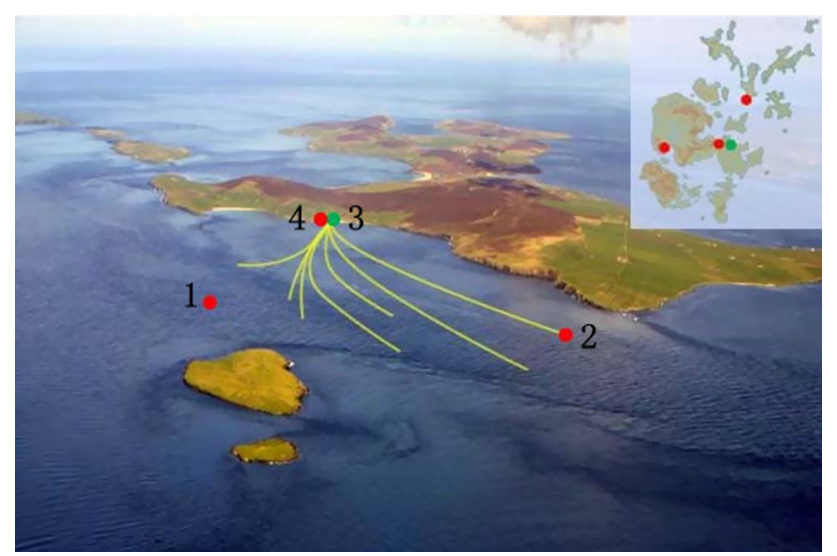

Fig. 4 Tidal current energy testing field of EMEC
The test berths are represented by Position in Fig. 4. The substation and meteorological station are represented by Position 3 and Position 4, respectively. The substation mainly includes high voltage switchyard, emergency power supply and communication lab, controlling the power generation process of each tidal current energy device and its connection to the state grid; the meteorological station offers real-time weather information and sends them to the data center.

With superior test conditions and extensive equipment, EMEC is the biggest ocean energy testing field with the largest diversity in test options, which supply the researcher and development institutes of oceanic renewable energy with a series of testing and verification services including major test facilities supply for tests of grid connection to the state grid, remote data monitoring and real-time analysis, verification during testing and performance evaluation process, and all guidance and assistance required in the examination and admittance process of the devices, etc. EMEC, as the incubator of wave energy and tidal current energy generation devices, is the only grid connection testing field recognized in the world for wave energy and tidal current energy generation devices until now.

\subsection{Wave Hub project in UK}

The construction of Wave Hub project in southwest of UK was finished in 2010. It is a large-scale grid-connected offshore testing field providing grid-connected experiments in real sea for various wave energy converters (WECs). As shown in Figs. 5 and 6 , it covers sea area of $8 \mathrm{~km}^{2}$, connecting to grid via $11 / 33 \mathrm{kV}$ submarine cables [20]. Wave Hub offers device testing services to WECs manufacturers from UK, Norway, Australia and the United States in real sea and fully monitored marine environment [21].

This project connects the WECs to power transmission lines of the National Grid of UK [22]. The voltage rating of the $25 \mathrm{~km}$ high-voltage submarine cable is $33 \mathrm{kV}$ rather than $11 \mathrm{kV}$. When operating at voltage rating of $11 \mathrm{kV}$, the system capacity is only $16 \mathrm{MW}$; in contrast, the system capacity will increase to $50 \mathrm{MW}$ when operating at the voltage rating of $33 \mathrm{kV}$. Additional cables of $1-4 \mathrm{~km}$ length are required to connect different WECs.

For each WEC, the rated power is $4 \mathrm{MW}$ and is connected to a transformer that escalates the $415 / 690 \mathrm{~V}$ terminal voltage of WEC to $11 \mathrm{kV}$. The Hayle substation on the bank is equipped with an $11 / 33 \mathrm{kV}$ transformer with power capacity of $20 \mathrm{MVA}$ and a nominal impedance of $10 \%$. What needs to be noted is that although the nominal capacity of the $33 \mathrm{kV}$ cable is $50 \mathrm{MW}$, capacity of the Hayle substation is only $30 \mathrm{MW}$. In order to adapt to the 


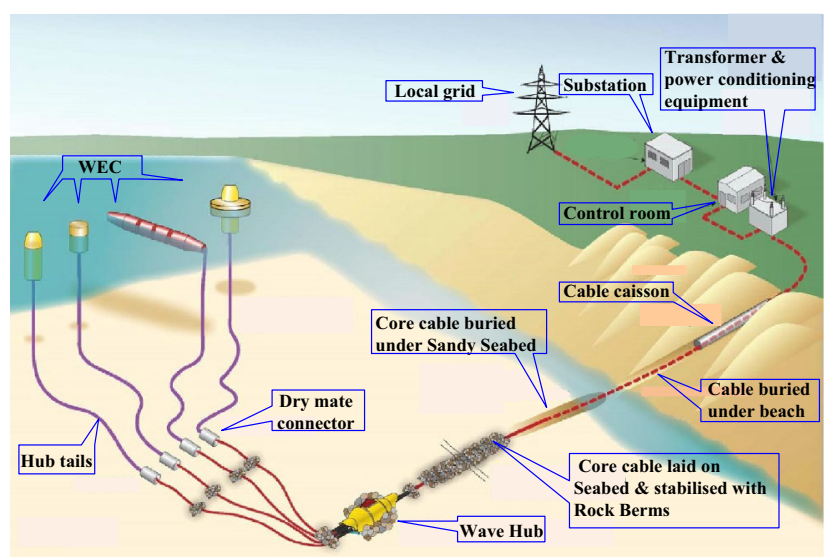

Fig. 5 Testing field of Wave Hub

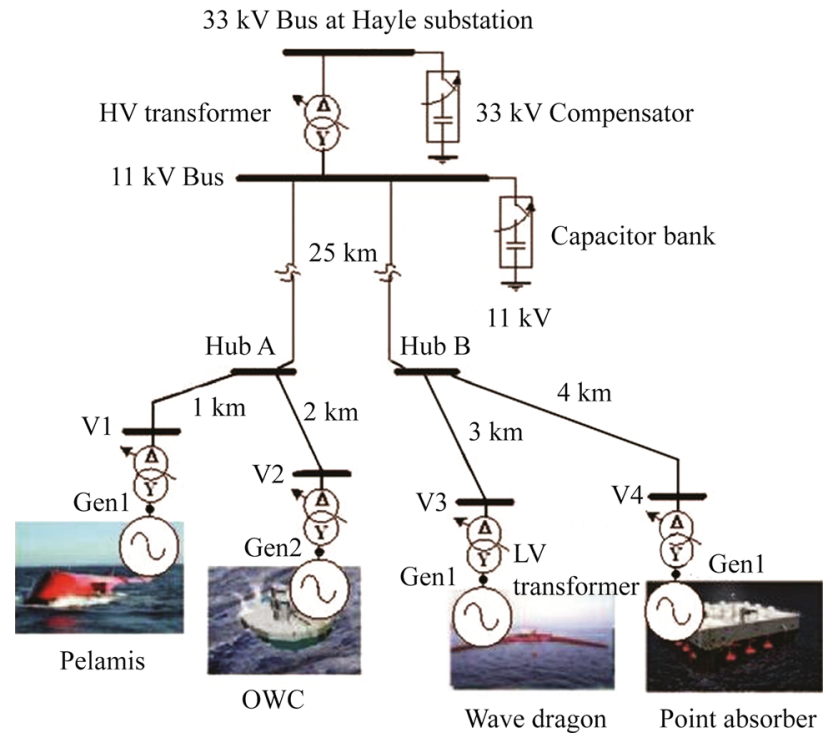

Fig. 6 Electric diagram of Wave Hub testing field

50 MW power rating, the substation should be connected to a $132 \mathrm{kV}$ system. Breakers are installed at all points of integration in order to isolate faults. Power factor correction equipment is needed to be installed in the substation in order to feed the grid with electricity satisfying various technical requirements.

Wave Hub project mainly conducts grid connection tests for devices including OWC, Wave Dragon, Pelamis, Point Absorber, etc. With extensive engineering equipment and relatively strong testing ability, a thorough evaluation of grid-connection performance of devices can be acquired from tests in the project. Besides performing grid-connection tests for more than one device at a time, the system volume can also be expanded, which is of great value in practice.

\subsection{Nissum Bredning testing field}

In 1998, the Wave Energy Association is established in Denmark to undertake management and supervision of wave energy research and development. So far, testing fields have been constructed in Nissum Bredning, northwest of Jutland. The facilities consist of a $5 \times 7 \mathrm{~m}$ platform, built in depth of $3.5 \mathrm{~m}$ and a $140 \mathrm{~m}$ long bridge connected the platform to the bank. The platform is equipped with an apparatus to record wind speed, wind direction, air temperature and wave height [23]. In 2003, the first prototype of Wave Dragon was tested, and was connected to the grid in the testing field. More than 30 different types of wave energy devices have been tested at Nissum Bredning Test Station, and Wave Star [24] is the main project under testing at the moment.

The test center, with a relatively strong technical supporting system, offers laboratory and on-site test environment for manufacture and modification of the device models. For the test platform is relatively small, simultaneous test of more than one device is not supported. For this reason, the test center usually performs tests with small-size independent device.

\subsection{Galway Bay testing field}

The Marine Institute and Sustainable Energy Authority of Ireland (SEAI) established an ocean energy testing field in Galway Bay, which can perform tests for $1 / 4$ scale prototypes of wave energy devices. Wavebob Ltd. was the first company to perform tests in the testing field and developed a prototype in 2006; Ocean Energy Ltd. completed the test of the Seilean wave energy prototype in 2009 [25]. Meanwhile, developers testing at this testing field should prepare mooring system and data acquisition system and transmission system themselves.

Because the testing field is inadequately-equipped, part of auxiliary equipment needs to be prepared by the personnel or institution conducting the test. Until now, only tests of power generation devices of two kinds of OWC wave energy can be performed in the testing field, indicating poor test conditions of the testing field, which does not suit for test for devices with complexity. To improve test conditions to reach an all-round test functions, relevant test auxiliary devices should be equipped.

\subsection{Development tendency of test platform}

At present, main application of ocean energy testing fields overseas is solely testing of power generation equipment, while only a few large-scale ocean energy testing fields are capable of grid-connected power 
generation at certain capacity. AC submarine cable is applied for power transmission when ocean energy testing fields are near to shore, and DC submarine cable is applied when ocean energy testing fields are far from shore, which is the future developing trend for test platform. For the time being, ocean energy generation platform will still exist in form of independent platform of wave energy, tidal current energy, etc. The unit capacity of ocean energy generation equipment is relatively small, therefore, same type of energy generation devices of different structures will be gathered in the test platform, and simultaneous testing of various types of energy generation devices will be performed. In general, future developing trend for energy generation platform are summarized as follows. More monitoring and testing system will be installed to make the energy generation platform more intelligent; more testing equipment will be involved, and thus the platform will be developing towards a larger scale. What's more, distance between test platforms and shore is getting larger and larger. Generating capacitor will increased and adaptive capacity under sea environment will be improved.

\section{Situation of domestic testing field}

\subsection{Necessity of testing field construction}

The ocean energy development in China is still at its initial stage. Some research institutes and companies are making great efforts to develop marine resources. In 2002, Harbin Engineering University independently designed and constructed the first $70 \mathrm{~kW}$ tidal current energy testing power station in China, and completed building a $40 \mathrm{~kW}$ tidal current testing power station named 'Universal II', which is categorized as submarine stationary vertical axis tidal current device. Northeast Normal University completed building a $1 \mathrm{~kW}$ underwater suspended horizontal axis tidal current device in 2008. Ocean University of China and China Academy of Machinery Science and Technology jointly developed a $5 \mathrm{~kW}$ tidal current energy generation device equipped with hydraulic turbine featured with flexible blades which passed tests in real sea in Qingdao in 2008. Zhejiang University developed a $5 \mathrm{~kW}$ and a $25 \mathrm{~kW}$ stationary horizontal axis tidal current device successively which both passed power generation tests in real sea. Until now, a $100 \mathrm{~kW}$ power station with oscillating water column (OWC) structure has been constructed in Shanwei City of Guangdong Province and a $30 \mathrm{~kW}$ pendulum wave energy testing power station in Daguang island of Qingdao. Guangzhou Institute of Energy Conversion affiliated with Chinese Academy of Science developed a $3 \mathrm{~kW}$, a $20 \mathrm{~kW}$ and a $100 \mathrm{~kW}$ land-based wave power testing station successively.
Unfortunately, most organizations are developing the key technologies independently which includes resource and topographic survey, device development, structural support, data collection, power system, etc. Inevitably, with the development of technologies, some problems emerge in this field [26]. Firstly, many common technical problems will be encountered. Some technical solutions under testing, e.g., construction of ocean test platform might overlaps, can be seen as a waste of investment. Secondly, during the stage of device development, construction and maintenance cost of supporting structure often occupy the largest part of the total cost. Thirdly, under different testing conditions, each research institute develops their devices separately, causing a lack of comparability between various types of devices. Finally, relevant organizations need to set up a unified standard, which could fully evaluates and certificates various ocean energy devices and provides references for technology promotion and thus reduces commercial risks.

The construction and utilization of offshore testing fields for wave energy and tidal current energy can provide a shared test platform, realize the integration and standardization of technology and solve the problems aforementioned effectively. So it is necessary to carry out related work as soon as possible through the support of National Special Funds, which guarantees the development of ocean energy in China [27].

\subsection{Construction plan of testing field in China}

At present, Taiwan is cooperating with Aquatera Ocean Energy Consulting Company in Scottish to launch advanced research and to select location for ocean energy offshore testing field.

In mainland, State Oceanic Administration launched a special fund project named 'Offshore Test and Test Site Construction and Engineering Design of Wave Energy and Tidal Current Energy' in 2010. It is also pointed out in the National Marine Affairs Development Plan Outline that science and technology laboratory and ocean energy testing field should be established through the integration of existing resources and based on principles of concentration, share, integrity and enhancement. During the twelfth fiveyear plan period, 2-3 ocean energy technology sharing platforms (testing fields) will be built sponsored by major projects of National High Technology Research and Development Program of China (863 Program).

On May 30, 2011, Marine Renewable Energy Development and Utilization Management Center of State Oceanic Administration held the "Coordination Committee on Wave Energy and Tidal Current Energy Test Site Selection' in Rongcheng, Shandong province, which is aimed at ensuring successful implementation of State Marine Renewable 
Energy Special Funds and promoting the construction of offshore testing fields for wave energy and tidal current energy. In this meeting the organizer conducted a sufficient communication and exchange of views with the invited specialists in civil ocean energy field and related departments of government on the position selection of testing field for wave energy and tidal current energy. Based on the analysis on historical material and examination on the spot, certain coastal areas of Shandong Province are primarily selected as the offshore testing field for wave energy and tidal current energy. Now, State Oceanic Administration of People's Republic of China is preparing to construct marine energy testing field in Shangdong province, and has done preparatory work of hydrologic survey of several sites and has finished the preliminary electrical design.

\section{Technological base of testing field construction in China}

Rongcheng is situated in the easternmost of Shandong Peninsula, surrounded on three sides by the sea. The energy density of wave energy and tidal current energy there are quite desirable. The measured maximum tidal current velocity is up to $2 \mathrm{~m} / \mathrm{s}$. Implementing the harmonic analysis method of short-term load flow [28] and FVCOM numerical model [29], it can be calculated that the average power density in surface, middle and bottom layer of Rongcheng outer waters is about $330 \mathrm{~W} / \mathrm{m}^{2}, 220 \mathrm{~W} / \mathrm{m}^{2}$ and $110 \mathrm{~W} / \mathrm{m}^{2}$, respectively. The vertical average power density is about $220 \mathrm{~W} / \mathrm{m}^{2}$ and the tidal current energy reserve in this area is about $18 \mathrm{MW}$ theoretically. Shengshandao is situated in the northernmost of Zhoushan islands in Zhejiang province. According to the statistics, the wave power value in Shengshan waters changes between $0.5 \mathrm{~kW} / \mathrm{m}$ and $8.8 \mathrm{~kW} / \mathrm{m}$ and the average wave power value is about 2.4 $\mathrm{kW} / \mathrm{m}$. The days in which wave power per meter facing the wave surface greater than $1 \mathrm{~kW}$ account for over $90 \%$ of the total statistical time and the frequency under which wave power value is $2 \mathrm{~kW} / \mathrm{m}$ distributes at about $6 \%$ [30].

Based on the demands of the first testing field for wave energy and tidal current energy in China, the National Ocean Technology Center conducted the design and development of testing field monitoring system according to site requirements and factory environment conditions, and then put forward the three-dimensional monitoring system made up of shore station observing system, wave rider observing system, medium-sized multi-parameter monitoring buoy system and large ocean data buoy system [31], which measures multiple parameters such as wave, tidal current, tidal level, temperature and salinity of the whole testing field. For wave energy power generation system, some quantitative evaluation indices on the power generation performance are presented on power, efficiency and economy aspects [32]. Reference [33] conducted research and design on the wave energy offshore test platform and proposed a semi-submersible platform according to the key performance parameters such as stability, movement performance and size of power generation device. A kind of test platform for tidal current energy generation device was put forward in reference [34]. The principal parts of the platform mainly include platform supporting system, carrying platform of power generation devices, maintenance platform, test system for electrical output of power generation device, power control platform and lightning protection system, etc. Through the research of output measurements and the design of grid-connected system about wave energy and tidal current energy devices, National Ocean Technology Center has accumulated a rich experience, which is of great importance to the construction and engineering design of ocean energy testing fields in China.

\section{Conclusion}

Following the initiative of Britain to establish EMEC, Irish, Denmark, the United States and other countries have successively built similar public grid-connection test platform in real sea. The IEA-OES commission is planning to perform a comprehensive assessment of the test ability in those offshore testing fields and establish relevant guidelines, aiming at providing references for the ocean energy research and development institutes and enterprises across the world on the selection of offshore testing fields for conducting tests in real sea.

In 2010, the State Oceanic Administration of China, together with the Ministry of Finance, formulated and promulgated the 'Interim Measures for Marine Renewable Energy Special Funds Management' and established 'Application Guidelines of Marine Renewable Energy Special Funds'. Various supporting projects have been carried out actively and continuously. However, there are still some problems on ocean energy development such as orientation, scale, layout, grid connection and electricity price, etc., which calls for an overall consideration and solution. Now it is especially necessary to accelerate project appraisal and construction work of wave energy and tidal current energy testing field, including on-site monitoring system design, setup of integrated comprehensive testing and evaluation system, engineering construction of testing field, etc. At the later stage, focus should be switched to the development of transmission system and the design of gridconnected interface to ensure the sustainable and healthy development of the ocean energy industry in China. 
Acknowledgment This work is supported by Marine Renewables Special Funds (No. GHME2012ZC02).

Open Access This article is distributed under the terms of the Creative Commons Attribution 4.0 International License (http:// creativecommons.org/licenses/by/4.0/), which permits unrestricted use, distribution, and reproduction in any medium, provided you give appropriate credit to the original author(s) and the source, provide a link to the Creative Commons license, and indicate if changes were made.

\section{References}

[1] Xiong Y, Wang H, Cui L et al (2009) Development strategy on development and utilization of marine renewable energy in China. Ocean Technol 28(3):106-110 (in Chinese)

[2] Zhu Y (2010) New energy and distributed generation technologies. Peking University Press, Beijing (in Chinese)

[3] Li Y, Luo X, Luo K (2013) Tide energy, wave energy test sites construction analysis of main problems. Ocean Dev Manag 2:36-39 (in Chinese)

[4] Wang TQ, Yuan P (2011) Technological economic study for ocean energy development in China. In: Proceedings of the IEEE international conference on industrial engineering and engineering management (IEEM'11), Singapore, 6-9 Dec 2011, pp 610-614

[5] Dalton G, Rosseau N, Neumann F et al (2009) Non-technical barriers to wave energy development, comparing progress in Ireland and Europe. In: Proceedings of the 8th European wave and tidal energy conference (EWTEC'09), Uppsala, Sweden, 7-10 Sept 2009

[6] Denniss T (2009) Tapping the energy of waves and tides. An IEA OPEN Energy Technology Bulletin Article, Issue No 64

[7] Frigaard P, Kofoed JP, Rasmussen MR (2004) Overtopping measurements on the Wave Dragon Nissum Bredning prototype. In: Proceedings of the 14th annual international offshore and polar engineering conference (ISOPE'04), Toulon, France, 23-28 May 2004

[8] OCEAN ENERGY. http://www.ocean-energy-systems.org/, 2013-10-4

[9] Marine Institute. http://www.marine.ie/Home/, 2013-10-4

[10] Sustainable Energy Authority of Ireland (SEAI): Belmullet wave energy test site. http://www.seai.ie/Renewables/Ocean Energy/AMETS/Belmullet_Test_Site/

[11] European Marine Energy Centre (EMEC). http://www.emec.org.uk/

[12] Huertas-Olivares C, Neumann F, Sarmento A (2007) Environmental management recommendations for the wave energy Portuguese pilot zone. In: Proceedings of the 7th European wave and tidal energy conference (EWTEC'07), Porto, Portugal, 11-13 Sept 2007

[13] Gillanders K, Harrington N, Taylor A (2005) Development of the South West Wave Hub. In: Proceedings of the 6th European wave and tidal energy conference (EWTEC'05), Glasgow, UK, 29 Aug - 2 Sept 2005, pp 175-182

[14] Mouslim H, Babarit A, Clément A et al (2009) Development of the French wave energy test site SEM-REV. In: Proceedings of the 8th European wave and tidal energy conference (EWTEC'05), Uppsala, Sweden, 7-10 Sept 2009

[15] AZTI. http://www.azti.es/

[16] Zhu Y, Duan C, Qing YE et al (2014) Research status on ocean energy generation test site in domestic and abroad. J Shanghai Ocean Univ 23(2):298-305 (in Chinese)
[17] Denison C (2011) Oregon wave energy test site selected. http:// www.earthtechling.com/2011/04/oregon-wave-energy-test-siteselected/

[18] Runde Miljøsenter. http://www.rundecentre.no/english/waveenergy-deployment.htm

[19] National Marine Technology Center (2010) Wave energy, tidal energy test site construction demonstration and project design program. National Marine Technology Center, Tianjin (in Chinese)

[20] Wave Hub. http://www.wavehub.co.uk/

[21] Rahm M, Bostrom C, Svenssön O et al (2010) Offshore underwater substation for wave energy converter arrays. IET Renew Power Gener 4(6):602-612

[22] Ahmed T, Nishida K, Nakaoka M (2011) The commercial advancement of $16 \mathrm{MW}$ offshore wave power generation technologies in the southwest of the UK. In: Proceedings of the 8th international conference on power electronics and ECCE Asia (ICPE \& ECCE'11), Jeju, Republic of Korea, 30 May-3 Jun 2011, pp 1476-1483

[23] Nordic Folkecenter: Nissum Bredning test station for wave energy. http://www.folkecenter.net/gb/rd/wave-energy/

[24] Tedd J (2007) Testing, analysis and control of Wave Dragon, wave energy converter. Ph D Thesis, Aalborg University, Aalborg, Denmark

[25] Sustainable Energy Authority of Ireland (SEAI): Galway bay test site. http://www.seai.ie/Renewables/Ocean_Energy/Galway_Bay_ Test_Site/

[26] Yuan P, Wang SJ, Shi HD et al (2012) Overview and proposal for development of ocean energy test sites in China. In: Proceedings of the OCEANS'12 MTS/IEEE conference, Yeosu, Republic of Korea, 21-24 May 2012, 6 pp

[27] Wei Q (2010) Promote the healthy development of Chinese marine. China Power Enterprise Manag 21:37-39 (in Chinese)

[28] Wu H, Zhao S, Xu H et al (2010) Preliminary assessment of tidal current energy on Chengshantou area. Ocean Technol 29(3):98-100 (in Chinese)

[29] Wu H, Wang X, Han L (2013) Assessment of extractable energy of tidal current at Chengshantou area. Ocean Limnol Sin 44(3):570-576 (in Chinese)

[30] Zhang Z, Xia Z, Liu J et al (2012) General design of renewable resources power generation system on islands. Ocean Technol 31(4):87-90 (in Chinese)

[31] Yang L, Wang X, Wang X et al (2013) Design of monitoring system for wave energy and tidal current energy test site. Ocean Technol 32(2):16-22 (in Chinese)

[32] Wang X, Li X, Wang J et al (2012) Study on the assessment of performance of the wave energy conversion systems. Ocean Technol 31(4):75-78 (in Chinese)

[33] Hou X, Li Y, Wang X et al (2013) Feasibility study on the design of wave energy test platform. Ocean Technol 32(2):23-26 (in Chinese)

[34] Song Y, Wang X, Wang X et al (2013) Analysis of tidal current energy generation devices test platform design. Ocean Dev Manag 9:49-51 (in Chinese)

Yongqiang ZHU received the B.S., M.S. and Ph.D degrees from Tsinghua University, Beijing, China. Now, he is an Associate Professor in NCEPU. His current research interests include power quality and new energy power generation technologies.

Lihu JIA received the B.S. degree from HBSTU, Hebei, China, in 2012. Currently he is pursuing the Ph.D degree at NCEPU. His research interest is new energy power generation technologies. 
Chunming DUAN received the B.S. and M.S. degrees from NCEPU, Beijing, China, in 2011 and 2014, respectively. He is working in State Grid Jibei Electric Economic Research Institute. His research interest is ocean energy power generation technologies.

Xiaoyan SUN received the B.Eng. form NCISC, Hebei, China, in 2012. Currently she is pursuing her master degree at NCEPU. Her research interest is new energy power generation technologies.
Wenrui GUO received the B.Eng. form NJUST, Jiangsu, China, in 2012. Currently he is pursuing his master degree at NCEPU. His research interest is new energy power generation technologies. 